Vol. 10(4), pp. 77-83, April 2016

DOI: 10.5897/AJPS2015.1389

Article Number: E31C6ED58265

ISSN 1996-0824

Copyright (C) 2016

Author(s) retain the copyright of this article

http://www.academicjournals.org/AJPS

\title{
Establishment and optimization of high efficiency embryogenic callus induction system in Dendrobium candidum
}

\author{
Nada Mohammed Reda Refish ${ }^{1}$, Linqing Wang ${ }^{1}$, Chunhua Fu1 ${ }^{2}$, Xiangping $\mathrm{Xu}^{1}$, Wenwen \\ $\mathrm{Jin}^{1,2 *}$, Maoteng $\mathrm{Li}^{1,3}$ and Longjiang $\mathrm{Yu}^{1,2}$
}

${ }^{1}$ Institute of Resource Biology and Biotechnology, Department of Biotechnology, College of Life Science and Technology, Huazhong University of Science and Technology, Wuhan, 430074, China.

${ }^{2}$ Key Laboratory of Molecular Biophysics of Ministry of Education, Wuhan 430074, China.

${ }^{3}$ Hubei Collaborative Innovation Center for the Characteristic Resources Exploitation of Dabie Mountains, Huanggang 435599, China.

Received 9 January, 2016; Accepted 16 April, 2016

\begin{abstract}
The wild resource of Dendrobium candidum, a well-known epiphytic orchid, is limited. Plant cell culture technology is a promising alternative for production of high-value secondary metabolites .In this research, factors affecting the induction, maintenance, and multiplication of callus from protocorm-like bodies (PLBs) of $D$. candidum were systematically studied, and a technical callus inducing system with $100 \%$ rate was established which higher than previously reported values. The result showed that 2,4dichlorophenoxy acetic acid(2,4-D) and 1-naphthalene acetic acid (NAA) could of benefit to the callus induction. The optimized medium for callus induction was MS medium containing $0.5 \mathrm{mg} / \mathrm{L} \mathrm{2,4-D}$ and 0.25 NAA or $0.5 \mathrm{mg} / \mathrm{L}$ kinetin (KT). The callus clump enrichment method was used for directional screening and cell adaptation on MS medium supplied with plant growth regulators (PGR) such as 5 $\mathrm{mg} / \mathrm{L}$ NAA and $0.5 \mathrm{mg} / \mathrm{L}$ 6-benzyladenine (6-BA) or KT for 30 days per cycle. After 6 to 9 months, $D$. candidum cell lines were obtained and the histological analysis showed that the main differences between callus and PLBs were meristematic cell content and internal cell differentiation degree, and the meristematic cells distributed in the external strip were contributed to the formation of callus. At last, the amount of polysaccharides and total amino acids were compared between the obtained cell lines, tissue culture seedlings and PLBs. The results showed that polysaccharides was $24.67 \%$ in callus and higher than that in tissue culture seedlings and PLBs. The amount of total amino acids was $5.94 \%$ in callus and higher than that in tissue culture seedlings. So the callus is considered a good choice for the expanding of $D$. candidum medicine sources.
\end{abstract}

Key words: Dendrobium candidum, Callus induction, tissue culture, natural products, plant growth regulators.

\section{INTRODUCTION}

Dendrobium candidum Wall. ex Lindl is a species that belongs to the Orchid family and a well-known orchid and epiphytic herb in South and Southeast Asian countries, which has been used as a Chinese traditional herb for over 1500 years (Leung, 2006). Modern pharmacological research has shown that $D$. candidum is an important 
Table 1. Effects of single plant growth regulators (PGRs)on callus inductionof $D$. candidum.

\begin{tabular}{lccccll}
\hline Medium & PIC & 2,4-D & NAA & Callus induction rate (\%) & Callus color & Callus status \\
\hline M1 & 0.25 & & & $2.1 \pm 0.35^{\mathrm{d}_{*}}$ & Brown & Died \\
M2 & 0.5 & & $9.4 \pm 0.85^{\mathrm{d}}$ & Brown & Died \\
M3 & 1.0 & & $0.9 \pm 0.28^{\mathrm{d}}$ & Brown & Died \\
M4 & & & $92.5 \pm 3.5^{\mathrm{ab}}$ & Yellow & Growth well \\
M5 & & & $100^{\mathrm{a}}$ & Yellow & Growth well \\
M6 & 1.0 & & $47.5 \pm 10.6^{\mathrm{c}}$ & Brown & Died \\
M7 & & & $27.3 \pm 5.9^{\mathrm{d}}$ & Brown & Died \\
M8 & & & & $89.5 \pm 6.2^{\mathrm{b}}$ & Yellow & Growth well \\
M9 & & & 5.0 & $83.2 \pm 8.1^{\mathrm{b}}$ & Yellow & Growth well \\
\hline
\end{tabular}

*All values are means \pm SE $(n=3)$. Mean values in each column followed by the same letter are not significantly different $(P<0.05)$ by the one-way ANOVA analysis.

candidate for modern drug development because it enhances immunity, exhibits antitumor activity, and other regulatory roles (Li et al., 2009; Luo et al., 2010; Xiao et al., 2011; Xing, 2013; Bian et al., 2002). The production of D. candidum in Yunnan was estimated to be lower than $1000 \mathrm{~kg}$ in 1998, which cannot meet the market (Huang et al., 1996), the development of $D$. candidum cultivation, is therefore necessary.

Plant cell, tissue, and organ cultures, such as callus, embryo (protocorm-like bodies, PLBs), and tissue culture seedlings, are complementary systems used to enhance the beneficial bioactivities of $D$. candidum (Kolewe et al., 2008). D. candidum can be micropropagated using explants, such as PLBs, protocorms, immature seeds, and shoot tips (Paulsen, 2001; Chen and Wang, 2005; Su and Yang, 2006) and there are also some studies focused on the induction, proliferation, and liquid culture of PLBs (Men et al., 2003; Shi and Zhao, 2012; Jasim et al., 2015). There is recently study on the PLBs suspension cultures of $D$. candidum in balloon type bubble bioreactors for the production of biomass and bioactive compounds such as polysaccharides, coumarins, polyphenolics, flavonoids, vitamin $\mathrm{C}$ and vitamin E (Cui et al., 2014). Plant cell culture is also a promising alternative for production of high-value bioactive compounds (Rao and Ravishankar, 2002; Ramawat and Merillon, 2008; Rischer et al., 2013). And there are only some report on the callus induction, but it is easy to differentiation into protocorm or PLB (Roy and Banerjee, 2003; Chen and Chang, 2000; Zhao et al., 2008), and there is no research on callus maintain or scale-up process for the production of bioactive compounds from $D$. candidum suspension cultures. The present study established an effective method for embryogenic callus induction and maintain, then the formation and characteristics of the callus were confirmed by anatomy analysis, at last, the amount of polysaccharides and total amino acids among different explants (tissue culture seedlings, callus, and PLBs) of $D$. candidum were compared to determine the most suitable methods for expanding $D$. candidum sources.

\section{MATERIALS AND METHODS}

\section{Plant materials and cultivation}

Shoot explants were obtained from wild Dendrobium plants in Yunnan province (which have been confirmed by a plant taxonmists named Xiang Jun in Huanggang normal university) were maintained on MS medium supplied with $1 \mathrm{mg} / \mathrm{L}$ thidiazuron (TDZ), $0.5 \mathrm{mg} / \mathrm{L}$ 1-napthalene acetic acid (NAA), and $0.5 \mathrm{mg} / \mathrm{L} \mathrm{2,4-}$ dichlorophenoxy acetic acid (2,4-D) at $25^{\circ} \mathrm{C}$ in the dark.

\section{Callus induction and cell line formation of $D$. candidum}

PLBs were used as explants and MS medium as the basic culture medium for callus induction. The effects of picloram, 2,4-D, NAA, kinetin (KT), and 6-benzyladenine (6-BA) and their combinations on callus induction were determined (Tables 1 and 2).Induction was performed in the dark at $25^{\circ} \mathrm{C}$. Twenty explants were inoculated for each experiment. The Callus induction rate and Browning intensitywere evaluated after 20 day of culture.

\section{D. candidum cell lines were obtained using the callus clump enrichment method}

The well-conditioned buff callus briquette was minced with forceps and inoculated in the subculture medium 1 (SCM1). This process was repeated several times, with the first three to four multiplication cycles for 15 days and multiplication cycles after 3 months were gradually extended to 20 day.

The subculture medium was adjusted to subculture medium 2

\section{*Corresponding author. E-mail: jww@hust.edu.cn. Tel: 86-27-87792264. Fax: 86-27-87792265.}


Table 2. Effects of plant growth regulators (PGRs) combinations on callus induction.

\begin{tabular}{|c|c|c|c|c|c|c|c|c|c|}
\hline Medium & 2,4-D & NAA & KT & 6BA & $\begin{array}{c}\text { Callus } \\
\text { formation } \\
\text { time (days) }\end{array}$ & $\begin{array}{c}\text { Callus } \\
\text { induction } \\
\text { rate }(\%) \\
\end{array}$ & $\begin{array}{l}\text { Browning } \\
\text { intensity }\end{array}$ & Growth state & $\begin{array}{l}\text { Re- } \\
\text { differentiation }\end{array}$ \\
\hline MC1 & 0.5 & & 0.25 & & 9 & $100^{\mathrm{a} *}$ & - & Good condition & + \\
\hline MC2 & 0.5 & & 0.5 & & 10 & $100^{a}$ & - & Good condition & + \\
\hline MC3 & 1.0 & & 0.25 & & 8 & $100^{a}$ & + & Grow well & ++ \\
\hline MC4 & 1.0 & & 0.5 & & 7 & $100^{a}$ & + & Grow well & ++ \\
\hline MC5 & & 5.0 & & 0.25 & 12 & $100^{\mathrm{a}}$ & - & Grow well & ++ \\
\hline MC6 & & 5.0 & & 0.5 & 12 & $100^{a}$ & - & Grow well & ++ \\
\hline MC7 & & 10.0 & & 0.25 & 14 & $85.0 \pm 7.1^{b}$ & ++ & Grow slowly & +++ \\
\hline MC8 & & 10.0 & & 0.5 & 14 & $87.5 \pm 3.5^{b}$ & ++ & Grow slowly & +++ \\
\hline MC9 & & 5.0 & 0.25 & & 12 & $100^{a}$ & - & Grow well & ++ \\
\hline MC10 & & 5.0 & 0.5 & & 12 & $100^{a}$ & - & Grow well & ++ \\
\hline MC11 & & 10.0 & 0.25 & & 13 & $85 \pm 7.1^{b}$ & ++ & Grow slowly & +++ \\
\hline MC12 & & 10.0 & 0.5 & & 13 & $87.5 \pm 10.6^{b}$ & ++ & Grow slowly & +++ \\
\hline
\end{tabular}

The Callus induction rate and Browning intensity were checked in $20^{\text {th }}$ day after the culturing, and growth state, re-differentiation were checked after 3 months culture. Re-differentiation:"+" means the re-differentiation rate is lower than $10 \%$; "++" means the re-differentiation rate is around $30 \%$, and "+++"means the re-differentiation rate is around 50\%. Browning intensity: "-" means no browning; "+" means a little browning; "++" means a heaven browning. . All values are means $\pm S E(n=3)$. Mean values in each column followed by the same letter are not significantly different $(P<0.05)$ by the one-way ANOVA analysis.

(SCM2), and the multiplication cycle was gradually extended from 20 to 30 day to adapt to the final consumption demand of $D$. candidum cell culture.

SCM1: MS + $0.5 \mathrm{mg} / \mathrm{L} \mathrm{2,4-D}+0.5 \mathrm{mg} / \mathrm{L} \mathrm{KT}+1 \%$ agar+3\% sucrose SCM2: MS $+5 \mathrm{mg} / \mathrm{L} \mathrm{NAA}+0.5 \mathrm{mg} / \mathrm{L} 6-\mathrm{BA}+1 \%$ agar+3\% sucrose.

\section{Anatomical analysis}

Anatomical analysis of PLBs and callus of $D$. candidum was conducted using paraffin sections according to the methods of Ennajeh et al. (2010) and Zhao et al. (2007). Photographs were obtained using a microscope (AH2, Olympus, Japan).

\section{Polysaccharide extraction and analysis}

Approximately $0.5 \mathrm{~g}$ of samples were collected, dried in an oven at $55^{\circ} \mathrm{C}$ for $20 \mathrm{~h}$, and then powdered using a mortar. The polysaccharides was obtained by water extraction and ethanol precipitation, and analyzed by phenol-sulfuric acid according to the method of Tong et al. (2015). Anhydrous glucose was used as a standard in determining the total polysaccharides content. From anhydrous glucose stock concentration of $0.09 \mathrm{~g} / \mathrm{L}$, several dilutions were made to prepare a series of concentrations at 0.2 , $0.4, \quad 0.6, \quad 0.8$ and $1.0 \mathrm{mg} / \mathrm{mL}$. A standard curve $\left(Y=0.0082 X+0.0036 . R^{2}=0.9992\right)$ was constructed with the optical density at $490 \mathrm{~nm}$ against the concentrations of glucose. The total polysaccharides content of the samples were expressed in milligram of glucose equivalent per gram of samples.

\section{Amino acid extraction and analysis}

Approximately $0.25 \mathrm{~g}$ of samples were dried in an oven at $55^{\circ} \mathrm{C}$, powered, and then transferred to tapered plug bottles. About $20 \mathrm{~mL}$ of $0.1 \mathrm{~mol} / \mathrm{L} \mathrm{HCl}$ solution was added, and the mixture was ultrasonicated at $30^{\circ} \mathrm{C}$ for $30 \mathrm{~min}$. The mixture was suctioned, and the $\mathrm{pH}$ was adjusted to 7 neutral with $15 \%$ hydroxide sodium solution. The samples were then transferred to $100 \mathrm{~mL}$ volumetric flasks and adjusted to $100 \mathrm{~mL}$ by adding distilled water. Briefly, 4.0 $\mathrm{mL}$ of the extract was transferred to a $10 \mathrm{~mL}$ tube and added with $1.0 \mathrm{~mL}$ of sodium acetate buffer salt solution $(\mathrm{pH} 6.5)$ with $1.0 \mathrm{~mL}$ of $2 \%$ ninhydrin solution. The mixture was heated in a water bath at $100^{\circ} \mathrm{C}$ for $40 \mathrm{~min}$ and cooled for $15 \mathrm{~min}$ before adjusting to $50 \mathrm{~mL}$ by adding water. Aspartic acid (HPLC $\geq 98 \%$, CAS: $5794-13-8$ ) was used as a standard in determining the total amino acid content From aspartic acid stock concentration of $0.1014 \mathrm{~g} / \mathrm{L}$, several dilutions were made to prepare a series of concentrations at 0.2 , $0.4,0.6,0.8$ and $1.0 \mathrm{mg} / \mathrm{mL}$. A standard curve $(\mathrm{Y}=13.93 \mathrm{x}-0.1799$, $\mathrm{R}^{2}=0.9996$ ) was constructed with the optical density at $568 \mathrm{~nm}$ against the concentrations of aspartic acid. The total amino acid content of the samples were expressed in milligram of aspartic acid equivalent per gram of samples.

\section{Statistical analysis for callus induction and cell line formation}

Each treatment was repeated three times, for polysaccharide and for amino acids analysis, each sample were extracted three times and measurements were repeated three times. Data are the mean values of three replicates, and are expressed as mean \pm standard error (SE). Statistical analysis was performed using one-way ANOVA using an SAS software package.

\section{RESULTS}

Effects of different plant growth regulators on the callus induction and cell line formation of $D$. candidum

Since the auxin could benefit to the callus induction in many genus, so the effect of the auxin analogues 


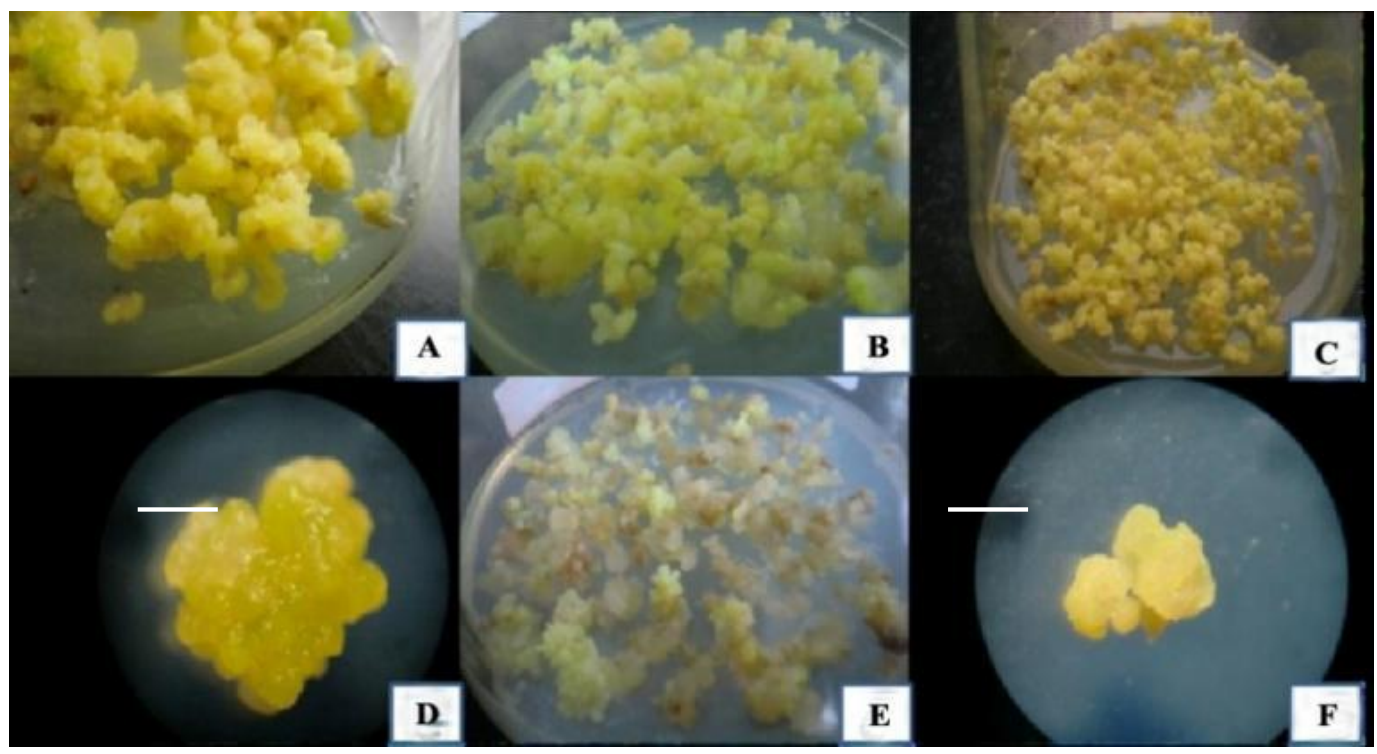

Figure 1. Cell acclimation of $D$. candidum. A, D: Initial subcultured cells; B, E: The differentiated cells during subculture; C,F: Cell lines formed after 3 months on SCM2 medium. The images in D, F were obtained under a stereo microscope at $20 \times$, the bar represent $1 \mathrm{~mm}$.

picloram, 2,4-D,NAA on the callus induction of $D$. candidum were examined. The results showed that PLB cultured on the medium containing picloram are all died, and callus could be induced on the medium containing 2,4-D (0.5 and $1.0 \mathrm{mg} / \mathrm{L})$ with high induced rate above $90 \%$, or NAA (5 and $10 \mathrm{mg} / \mathrm{L}$ ) with a induced rate around 80 to $90 \%$ (Table 1). But the calli induced on the MS medium supplied with 2,4-D alone gradually became brown. Then the effects of MS medium supplied with 2,4$D$,NAA and cytokinin on the callus induction were further carried out. The results showed that the supply of cytokinin could benefit to the callus inductionand 2,4-Dtreated group showed visible calli within 7 to 10 day. On day $20, \mathrm{MC} 1, \mathrm{MC} 2, \mathrm{MC} 3$, and MC4 media containing 2,4$\mathrm{D}$ and KT obtained $100 \%$ callus induction rate. The callus induced on MC1 and MC2 medium containing $0.5 \mathrm{mg} / \mathrm{L}$ 2,4-D showed no browning, and were in good conditions with slight re-differentiation rate when transferred to subcultured medium SCM1 to form cell line. The callus appeared a slight browning on MC3 and MC4 medium

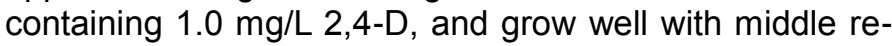
differentiation rate on SCM1 medium. The callus mass gradually appeared after 12 to 14 day culture on medium containing NAA and 6-BA or KT. The callus induction rate on medium (MC5, MC6, MC9, MC10) containing $5 \mathrm{mg} / \mathrm{L}$ NAA was also $100 \%$, the calli presented a pale yellow color with almost no browning, and grow well with no redifferentiation on SCM1 medium. The calli induction rate were around $85 \%$ on medium (MC7, MC8, MC11, MC12) containing $10 \mathrm{mg} / \mathrm{L} \mathrm{NAA}$, the calli showed some browning, and grow slowly with a heavy browning.

As differentiation into seedlings easily occurs during cell line establishment for $D$. candidum, culture conditions must be controlled during domestication. The newly induced callus of $D$. candidum presented a dense structure with large clumps (Figure $1 A$ and $D$ ). Some callus became brown and necrotic, whereas the other parts appeared to be differentiated during subculture (Figure $1 \mathrm{~B}$ and $\mathrm{E}$ ). A strong tendency toward callus differentiation was observed in the initial subculture. This finding indicated that short subculture periods (15 day) were necessary in the first three to four cycles. Clumps were crushed to granules during sub-inoculation. After 3 months of continuous screening and domestication on medium SCM1, the texture of the callus became visibly loose, granules became stronger and more evident, and the re-differentiation tendency gradually weakened on medium SCM2 (Figure 1C and F).

\section{Comparison of anatomical characteristics between callus and PLBs of $D$. candidum}

Callus and PLBs were selected for paraffin sectioning. The results showed the initial PLB contained a small number of meristematic cells distributed in a strip in the near surface zone of tissues, whereas the internal part was composed of non-meristematic cells with few inclusions and large particle sizes (Figures 2A to $\mathrm{C}$ ). Callus was mainly composed of square or circular meristematic cells with strong division ability and large nuclei. Some cells do division and present a dual-core state (Figures 2D to $F$ ). That suggested the main differences between callus and PLBs were meristematic cell content and internal cell differentiation degree, and the meristematic cells distributed in the external strip 


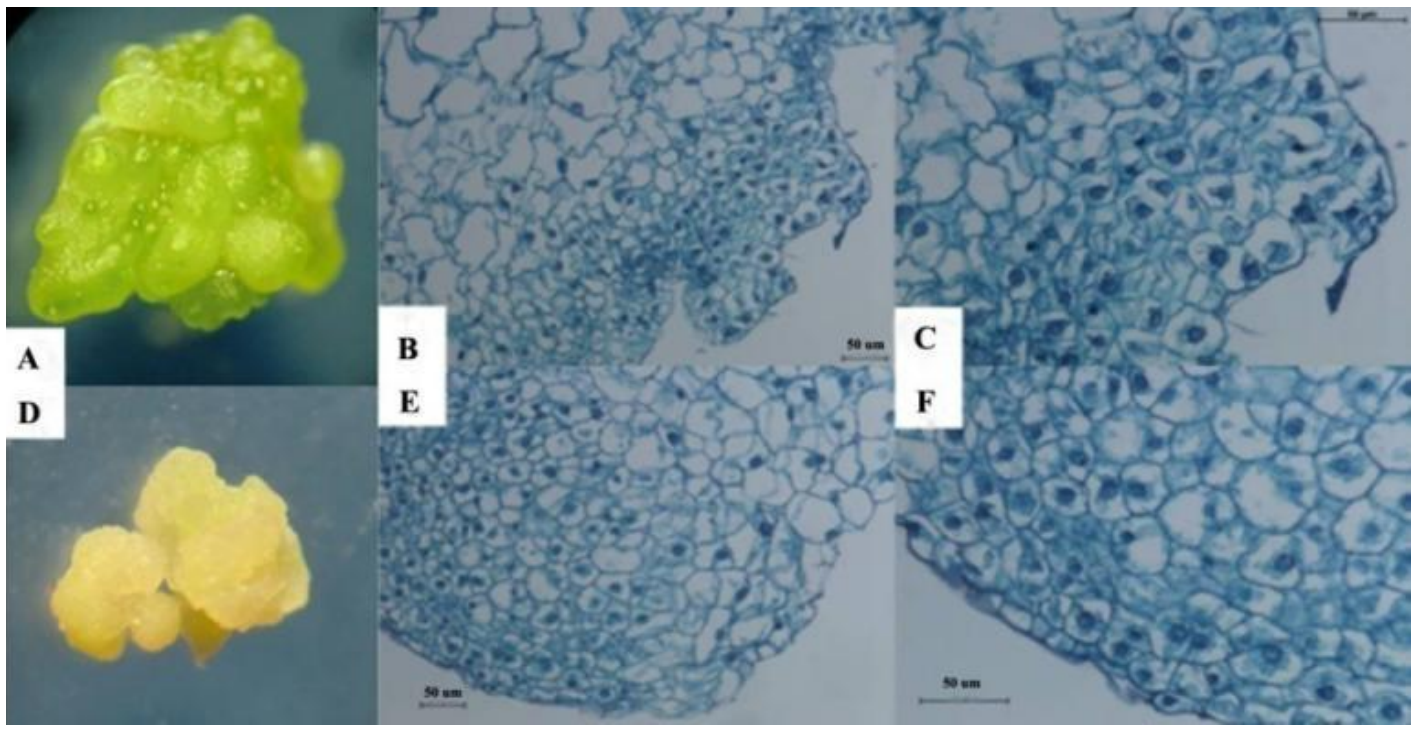

Figure 2. Comparison of the microstructure of protocorm-like bodies(A-C) and callus (D-F) of $D$. candidum.

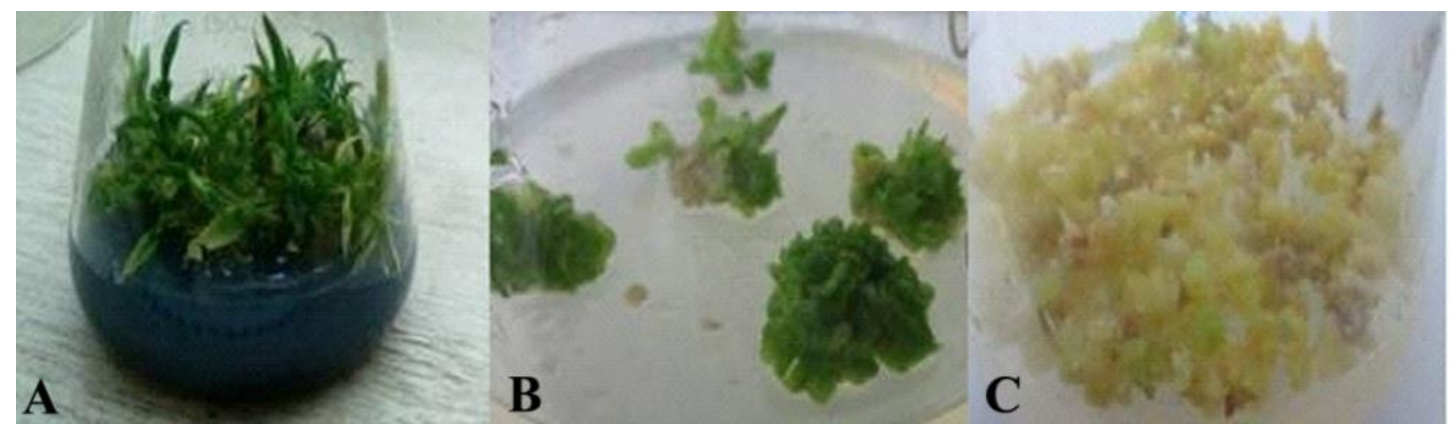

Figure 3. Three different in vitro cultures of $D$. candidum. A. Tissue culture seedlings; B. protocorm-like bodies (PLB); and C. callus.

Table 3. Polysaccharides and Amino acid compounds content in different $D$. candidum cultures.

\begin{tabular}{lcc}
\hline Parameter & Polysaccharides content (\%) & Amino acid content (\%) \\
\hline Callus & $24.67 \pm 0.102^{\mathrm{a}_{*}}$ & $5.94 \pm 0.490^{\mathrm{b}}$ \\
Protocorm-like bodies (PLB) & $17.01 \pm 0.716^{\mathrm{b}}$ & $14.06 \pm 0.104^{\mathrm{a}}$ \\
Tissue culture seedlings & $13.80 \pm 0.602^{\mathrm{c}}$ & $3.34 \pm 0.180^{\mathrm{c}}$ \\
\hline
\end{tabular}

${ }^{*}$ All values are means \pm standard error $S E(n=3)$. Mean values in each column followed by the same letter are not significantly different $(P<0.05)$ by the one-way ANOVA analysis.

were contributed to the formation of callus.

\section{Quality analysis of different kinds of tissue cultures from $D$. candidum}

The major bioactive compounds of $D$. candidum are polysaccharides (Liu et al., 1988; Yi et al., 1999). The main active compounds (polysaccharides and amino acid) were compared among different in vitro cultures (tissue culture seedling, callus, and PLBs) of $D$. candidum (Figure 3 ) to evaluate the possibility of producing useful plant bioactivities using plant cell culture (Table 3). The results showed that polysaccharide content was significantly higher $(24.67 \%)$ in callus than that in the PLBs and tissue culture seedlings $(P<0.05)$. Another 
major compounds of total amino acids were also checked, the amount of total amino acids was $5.94 \pm 0.490 \%$ in callus and higher than that in tissue culture seedlings, but lower than that in the PLBs (Table $3)$.

\section{DISCUSSION}

In the present research, factors affecting the induction, maintenance, and multiplication of callus of $D$. candidum were systematically studied. An efficient method was established for callus induction and cell line construction and maintenance, and major bioactive compounds were compared among different in vitro cultures (tissue culture seedling, callus, and PLBs) of $D$. candidum. The results showed that calli exhibit the highest potential as an alternative medicine source. But for the plant cell culture, plant tissue de-differentiation is the key to callus formation and the induction efficiency was affected by several factors such as explant, plant growth regulators (Tao et al., 2011; Prakash et al., 1996; Nayak et al., 2002). In the de-differentiation induction of $D$. officinale, the highest callus induction rate reached $82 \%$ and was achieved using seed-induced PLBs as explants (Zhao et al., 2008). The highest callus induction rate reached $86.67 \%$ when tender stem segments were used as explants (Wang and Liang, 2010), and there is a novel study illustrate shedding light on the effect of various plant growth regulator 2,4-DandNAAon callus induction of ricinus commun. Callus culture was initiated from cotyledonary leaf and root segments explants from in vitro Ricinus communis $L$ seedling. The results showed that 2,4-D and NAA effecting the callus agitation, but 2,4$D$ was proved to be more efficiency for induction of callus. Individual treatment of NAA reveals low effectiveness for callus induction (Khadiga et al., 2015). In the current study, PLBs (which was defined as somatic embryos in orchids species, Lee et al., 2013) was used as explants and the callus induction rate reached $100 \%$ under the optimized condition which was MS medium containing $0.5 \mathrm{mg} / \mathrm{L} 2,4-\mathrm{D}$ and $0.25 \mathrm{NAA}$ or $0.5 \mathrm{mg} / \mathrm{L}$ kinetin (KT). The callus clump enrichment method was used for directional screening and cell adaptation on MS medium supplied with plant growth regulators (PGR) such as 5 $\mathrm{mg} / \mathrm{L} \mathrm{NAA}$ and $0.5 \mathrm{mg} / \mathrm{L} 6$-benzyladenine (6-BA) or KT for 30 days per cycle. While in another study for Dendrobium Broga Giant, the percentage of PLBs induced was the highest on half strength MS semi-solid medium supplemented with $1.0 \mathrm{mg} / \mathrm{L} \mathrm{BAP}$ and $0.5 \mathrm{mg} / \mathrm{L}$ NAA. The highest proliferation rate of $8.7 \%$ of PLBs was obtained in $1.0 \mathrm{mg} / \mathrm{L} \mathrm{BAP}$ and $0.5 \mathrm{mg} / \mathrm{LNAA}$ (Jasim et al., 2015).

But the establishment of $D$. candidum cell line is challenging, and requires a long period of acclimation. At the beginning of subculture, $D$. candidum cells exhibit a strong ability to re-differentiate and gradually gain the ability to maintain the dedifferentiation state. Plant growth regulator is the key factor to regulate the cell differentiation state. The early subculture cycle of $D$. candidum cell lines is insufficient to maintain the hormone levels in the culture medium above the threshold and thus cannot maintain the cell dedifferentiation state. Meanwhile, plant cell differentiation is controlled by the position effect, changing the cell position appropriately in the critical period before cell division could change cell development mode (Wolpert, 1969). In the subculture of $D$. candidum, cell granulation could be induced by changing the cell position by using tweezers to constantly mince callus.

Polysaccharides are the main components of $D$. candidum, and polysaccharide content is positively correlated with physiological function. Hence, the content of polysaccharides should be the widely accepted evaluation criterion for $D$. candidum and its use as a medicine source. Controlled cell culture conditions are conducive to the implementation of good manufacturing practices and short production cycles to generate medicines from $D$. candidum. Plant cultivation for medicinal purposes will also minimize wild collection, thus supporting plant conservation in the wild. However, total polysaccharide content of cultivated plants must be comparable with the wild plantlets from Yunnan, in which the total polysaccharide ranges from 18 to $46 \%$ (Jiang et al., 2014). In the current study, we found that calli possessed the highest polysaccharide content of $24.67 \%$, and exhibit the highest potential as an alternative medicine source for $D$. candidum.

\section{Conclusions}

An effective method was established for embryogenic callus induction and maintenance of $D$. candidum. The proposed method included PLB induction under the optimized condition, callus induction and growth, and callus maintenance. The callus induction rate under the optimized conditions was $100 \%$ and higher than previously reported values. And the major bioactive compounds of polysaccharidesin callus are higher than in tissue culture seedling and protocorm-like bodies. Therefore, callus maybe a suitable material for utilization of $D$. candidum as a medicine source.

\section{Conflict of interests}

The authors hereby declare that no conflict of interest exists among them.

\section{ACKNOWLEDGEMENTS}

This work has been supported by the National Natural 
Science Foundation of China (31270342), National "11th Five-Year Plan" to Support Science and Technology Project of China (2008BAI63B04). The authors are grateful to the Analytical and Testing Center, Huazhong University of Science and Technology.

\section{Abbreviations}

6-BA, 6-benzyladenine,2,4-D 2,4-dichlorophenoxyacetic acid; Kin, kinetin; MS, Murashige and Skoog (1962) medium; NAA, Naphthaleneacetic acid; PLBs, Protocorm-like bodies; TDZ, thidiazuron; PIC, picloram.

\section{REFERENCES}

Bian HW, Wang JH, Lin WQ, Han N, Zhu MY (2002). Accumulation of soluble sugars, heat-stable proteins and dehydrins in cryopreservation protocorm-like bodies of Dendrobium candidum by the air-drying method. J. Plant Physiol. 159:1139-1145.

Chen JT, Chang WC (2000). Efficient plant regeneration through somatic embryogenesis from callus cultures of Oncidium (Orchidaceae). Plant Sci. 160(1):87-93.

Chen YG, Wang HY (2005). Advance on the chemical and pharmacological studies on plants of Flickingeria genus. Lishizhen Med. Mater. Med. Res. 16:725-727.

Cui HY, Murthy HN, Moh SH, Cui YY, Lee EJ, Paek KY (2014). Production of biomass and bioactive compounds in protocormcultures of Dendrobium candidum Wall ex Lindl. using balloontype bubble bioreactors. Ind. Crops Prod. 53:28-33.

Ennajeh M, Vadel AM, Cochard H, Khemira H(2010).Comparative impacts of water stress on the leaf anatomy of a droughtresistant and a drought sensitive olive cultivar. J. Hortic. Sci. Biotechnol. 85(4):289294.

Huang MQ, Cai TY, Liu QL (1996). Effects of polysaccharides from Dendrobium candidium on white bloodcells and lymph cell moving inhibition factor of mice. Nat. Prod. Res. Dev. 8(3):39-41.

Jasim U, Pavallekoodi G, Latiffah Z, Chew BL, Sreeramanan S (2015). Theeffect of different growth media,carbon source and PGRs on Dendrobium Broga Giant orchids protocorm like bodies PLBs proliferation supported with SEM and TEM analysis, School of Biological Sciences, Universiti Sains Malaysia, Georgetown, 11800 Penang, Malaysia.

Jiang W, Jiang B, Mantri $\mathrm{N}$,Wu Z, Mao L, Lu H, Tao Z (2014).Comparative Eco physiology analysis of photosynthesis, biomass allocation, polysaccharide and alkaloid content in three Dendrobium candidum cultivars . Plant Omics. 7(2):117-122

Khadiga GAE, Magda MA, Moawiya KMN (2015). Effect of Explants and Plant Growth Regulators onCallus Induction in Ricinus communis L, Department of Biology and Biotechnology, Faculty of Science and Technology. AL Neelain University, SUDAN, Commission of Biotechnology and Genetic Engineering, National Centre for Research, Sudan.

Kolewe ME, Gaurav V, Roberts SC (2008).Pharmaceutically active natural product synthesis and supply via plant cell culture technology. Mol. Pharm. J. 5(2):243-256.

Lee Y, Hsu ST, Yeung EC (2013). Orchid protocorm-like bodies are somatic embryos. Am. J. Bot. 100(11):2121-2131.

Leung PC (2006). Good agricultural practice-GAP: Does it ensure a perfect supply of medicinal herbs for research and drug development? In: Leung PC, Fong HHS, Xue CC (eds.) Current review of Chinese medicine: quality control of herbs and herbal materials, World Scientific Publishing Co. Pte. Ltd, Singapore. pp. 2755.
Li Y, Wang CL, Wang YJ, Guo SX, Yang JS, Chen XM, Xiao PG (2009). Three new bibenzyl derivativesfromDendrobium candidum. Chem. Pharm. Bull. 57:218-219.

Liu RJ, Meng AD, Deng XQ, Li YR (1988).Seedling rapid propagation of Dendrobium candidum. Acta Pharm. 23:636-640.

Luo AX, He XJ, Zhou SD, Fan YJ, Luo AS , Chun Z (2010).Purification, compositionanalysis and antioxidant activity of the polysaccharides. Carbohydr. Polym. 79:1014-1019.

Men S, Ming X, Liu R, Wei C, Li Y (2003). Agrobacterium-mediated transformation of a Dendrobium orchid. Plant Cell Tissue Organ Cult. 75(1):63-71.

Nayak NR, Sahoo S, Patnaik S, Rath SP (2002).Establishment of thin crosssection (TCS) culture method for rapid micropropagation of Cymbidiuma loifolium (L.) Sw. and Dendrobium nobile Lindl. (Orchidaceae). Sci. Hortic. 94:107-116.

Paulsen BS (2001). Plant polysaccharides with immune stimulatory activities. Curr. Organ. Chem. 5:939-950.

Prakash L, Lee CL, Loh CS, Goh CJ (1996). In Vitro Propagation of Commercial Orchids: An assessment of Current Methodologies and Development of a Novel Approach-Thin Cross-Section Culture, Oxford and IBH Publishing Co. Pvt. Ltd., New Delhi. pp. 42-49.

Ramawat K, Merillon S (2008). Secondary metabolite production from plant cell cultures: the success stories of rosmarininc acid. Plant Cell Tissue Organ Cult. 16:85-100.

Rao RS, Ravishankar GA (2002). Plant tissue cultures: chemical factories of secondary metabolites. Biotechnol. Adv. 20:101-153.

Rischer H, Hakkinen ST, Ritala A, Seppanen-Laakso T, Miralpeix B, Capell T, Christou P, Oksman-Caldentey K (2013) Plant Cells as Pharmaceutical Factories. Curr. Pharm. Des. 19:5640-5660.

Roy J, Banerjee N (2003). Induction of callus and plant regeneration from Shoot tip explants of Dendrobium firmbriatum Lindl. var. oculatum Hk.f. Sci. Hortic. 97:333-340.

Shi J, Zhao R (2012). Study on the liquid suspension culture of Dendrobium candidum Wall. ex Lindl. seeds. Med. Plant. 3(4):3335.

Su H, Yang Y (2006). State quo of Dendrobium spp. resources of Nabanhe Nature Reserve and counter measures for protection. For Invent Plan 31:100-102.

Tao J, Liqin Y, Zhao D (2011). Effects of plant growthregulators on In vitro propagation of Cymbidium faberi Rolfe. Afr. J. Biotechnol. 10(69):15639-15646.

Tong H, Mao D, Zhai M, Zhang Z, Sun G, Jiang G (2015).Macrophage activation induced by the polysaccharides isolated from the roots of Sanguisorba officinalis. Pharm. Biol. 53(10):1511-1515.

Wang LP, Liang SY (2010). Study on the Protocorm-like bodies induction and propagation of Dendrobium. Chin. Agric. Sci. Bull. 26(1):265-268.

Wolpert $L$ (1969). Positional information and the spatial pattern of cellular differentiation. J. Theor. Biol. 25(1):1-47.

Xiao L, Ng TB, Feng YB, Yao T, Wong JH, Yao RM, Li L ,Mo FZ, Xiao Y, Shaw PC, Li ZM, Sze SC, Zhang KY(2011). Dendrobium candidum extract increases the expressionof aquaporin-5 in labial glands from patients with Sj"ogren'syndrome. Phytomedicine 18:194-198.

Xing X, Cui SW, Nie S, Phillips GO, Goff HD, Wang Q (2013). A review isolation process, structural, characteristics, and bioactivities of water-soluble polysaccharides from Dendrobium plants. Bioact. Carbohydr. Diet. Fibre 1:131-147.

Yi HF, Qi XJ, Zhou WT, Yue H(1999). Prospect seedling rapid development, ex vitro establishment of Dendrobium candidum and determination of polysaccharide. Chin. Tradit. Patent. Med. 21:658659.

Zhao P, Wang W, Feng FS, Wu F, Yang ZQ, Wang WJ (2007). High frequencyshoot regeneration through transverse thin cell layerculture in Dendrobium CandidumWall. Ex Lindl. Plant Cell Tissue Organ Cult. 90:131-139.

Zhao P, Wu F, Feng FS (2008).Protocorm-like body (PLB) formation and plant regeneration from the callus culture of Dendrobium candidum Wall ex Lindl. In Vitro Cell Dev. Biol. Plant 44(3):178-185. 